\title{
CONSIDERATION AND UTILIZE OF LIBRARY WEB RESOURCES BY FACULTY OF ENGINEERING COLLEGE IN EAST GODAVARI DISTRICT, ANDHRA PRADESH: A STUDY
}

\author{
B. Vinoda $1 \bowtie$, Dr. B. R. Doraswamy Naick ${ }^{2} \square$ (iD \\ ${ }^{1}$ Library Professional, AIIMS, Mangalagiri, Andhra Pradesh, India \\ ${ }^{2}$ Associate Professor and Head, Department of Library \& Information Science JNTUK, Kakinada, Andhra Pradesh, \\ India
}

Received 5 November 2021

Accepted 17 December 2021

Published 31 December 2021

\section{CorrespondingAuthor}

B. Vinoda, winoda.bharatha@gmail.com DOI

10.29121/granthaalayah.v9.i12.2021 .4455

Funding: This research received no specific grant from any funding agency in the public, commercial, or not-for-profit sectors.

Copyright: (C) 2021 The Author(s). This is an open access article distributed under the terms of the Creative Commons Attribution License, which permits unrestricted use, distribution, and reproduction in any medium, provided the original author and source are credited.

\section{ABSTRACT}

Digital information resources are fetching more and more imperative for the academic community. The increase of technical colleges in Andhra Pradesh are quiet noteworthy and in advance of various states of India. Digital resources are measured as imperative resources of teaching, research and training. Consequently, digital resources play a important role in academic libraries as they are mostly jingle for the support of academic brilliancy and research. For these research questionnaires were distributed to the faculty members of 10 selected engineering colleges in East Godavari district of Andhra Pradesh. Accordingly, 400 questionnaire distributed amongst the faculty members of 10 engineering colleges. Out of 400 , only 336 questionnaires were received back that is the overall response rate is $84 \% . .27 .98 \%$ of the faculties are utilize digital resources for bring up to date Knowledge. It is also found from the study that preponderance of the faculty members were satisfied with available digital resources.

Keywords: Digital Library, Engineering Colleges, Faculty Members and Digital Resources

\section{INTRODUCTION}

Digital library is a place in which collections are accumulated in digital formats and reachable by computer terminals. Digital library is creation the library endure a transform in the model of its role to produce, organize and distribute information resources. A digital library is a distributed electronic collection that covers almost all fields of human Endeavour to serve a distinct community.

Digital libraries play a momentous role in engineering libraries, as they are habitually tuned for the encouragement of academic distinction and research. The main objective of an engineering college library is to assist engineering professionals in enhancing and updating their knowledge and skills in engineering education and research. The principal role of engineering college library is to collect and organize record information in engineering and connected subjects to meet the needs of the users.

Engineering college libraries in Andhra Pradesh offer diverse information services and resources including SDI(selective Dissemination of Information) and end-user guidance. They pledge the digital resources such like E-books, Ejournals, CD-ROM databases, online databases, web base resources and a assortment of other digital resources. This study focuses on the present status of 
availability of digital resources in engineering institutions and also studies the attentiveness and utilize of library digital resources by the faculty of engineering college libraries located in East Godavari district, Andhra Pradesh.

\section{LITERATURE REVIEW}

Deenadhayalu (2021) Studied ISB of faculty of 41 engineering colleges in Rayalaseema region, bring into being that more than $50 \%$ of the faculty facing trouble while seeking information in their libraries, nearly $50 \%$ of faculty were not proverbial with e- resources, nearly $60 \%$ of faculty using google for search for their essential information.

Singh and Mahajan (2021) found that majority of research scholars $60.7 \%$ across the libraries were aware about e-resources being subscribed by their respective libraries nearly $30 \%$ of users access electronic resources twice a week, nearly $40 \%$ of users were satisfied from the electronic collection available in their respective libraries.

Naik and Kumar (2021) studied to distinguish the consideration of library resources and services. The majority $74.86 \%$ t of student pleased with reading space for reading room and $57.43 \%$ of users were stated that satisfied with physical facilities, available in the library. Suggested collection of library and other operation must be automated to meet the users' needs quickly and promptly.

Meenu and Mini (2021) found that the below half of the users were satisfied with the collection of resources. 63.50percent of the users ware satisfied with utilize of print resources. Only $31.50 \%$ were satisfied by utilize of electronic resources. 47.24 percent of the students said that none availability of various copies are the main crisis in utilizing print resources.

Kumar et al. (2021) found that nearly half of respondents using lending services, students stated that the main predicament is information is too vast, there is no significant difference in the purpose of visit to Library and colleges of users, there is a significant difference in the Problems facing while using library resources and services used by the users and colleges of users, and a significant difference in the Problems facing while using library resources and services used by the users and colleges of users.

Bhat et al. (2021) recognized the awareness on collections of library and services and assessed the satisfaction of users with library resources and services, 84 percentage of users are aware of e-question papers, 80 percentage of users of eBooks, 76 percentage of users aware of e-newspapers 42 percentage of respondents experience internet speed is low, 36.54 percentage of users feel be short of of training. is the problem in finding information from library, 38percentage of users suffer lack of computer facility, 32.69 percentage of respondents find be short of of time in finding information.

Vinoda et al. (2021) stated that faculty members highly depended on books for getting relevant informal sources for their academic requirements, majority of faculty 76.43 percent facing difficulty to seek information is lack of time, that means faculty are busy with other things than information gathering, there is significant difference in the Sources of information generally use between the faculty, in the level of dependency between the faculty members with regard to books, Reference Books, thesis and dissertations, conference proceedings, technical R\&D reports, Standards and patent specifications, to official documents in engineering departments, reprints and preprints from fellow professionals, abstracting the indexing sources/ journals (including online/ CD-ROM), personal collections, trade 
catalogues, and Audio/ Video recordings for getting relevant sources for their requirements

Pitla et al. (2020) studied $63.54 \%$ of respondents are male users, more than half of users were assistant professors, $36.73 \%$ of respondents visit the library on a daily basis, $89.50 \%$ respondents who feel that the library had convenient working hours, found that majority of user's visits library for borrowing books, reference books and electronic journals, majority of users use IEEE, SCOPUS, Springer, NPTEL services, users highly satisfied with IEEE database, DELNET resources, NPTEL lectures and $59.43 \%$ are not availing the facility of CMIE Prowess, suggested that the users are not aware of about some electronic information resources, so the engineering college libraries will conduct information literacy programmes on electronic resources.

\section{OBJECTIVES OF THE STUDY}

- To recognize the engineering college libraries provided that digital library resources and services.

- To study the different types of digital library resources and services.

- To identify the attentiveness and utilize of different types of digital resources.

- To examine the purpose and consumption of the digital library resources.

- To examine the levels of knowledge in the use of digital resources and services.

- To discover out the troubles faced by the faculty whereas admittance and utilizing digital resources.

\section{SCOPE AND LIMITATIONS OF THE STUDY}

The scope of the study is limited to the faculty members of engineering colleges in East Godavari district of Andhra Pradesh, as the study is to know the Awareness and Use of Web based Library resources. There are many engineering colleges in East Godavari, but a few of them have recognized digital library in their college libraries. Based on the establishment year and accessibility of digital resources of library, only 10 engineering colleges were selected in this study.

\section{METHODOLOGY}

The survey technique was adopted to collect chief data on this investigation exploration. The data is collected was prepared to achieve the above objectives. These questionnaires were disseminated to the libraries and the faculty members of 10 selected engineering colleges in East Godavari district of Andhra Pradesh. Accordingly, 400 questionnaire were distributed among the faculty members of 10 engineering colleges. Out of 400, only 314 questionnaires were received back that is the overall response rate is $78.5 \%$. The collected data was tabulated and analyzed with the applications of simple statistical tools.

\section{DATA ANALYSIS}

Table 1 Basic information about selected engineering colleges

\begin{tabular}{|c|c|c|c|}
\hline Name of the college & Affiliation & $\begin{array}{c}\text { Year of } \\
\text { Establishment }\end{array}$ & Code \\
\hline
\end{tabular}




\begin{tabular}{|c|c|c|c|}
\hline $\begin{array}{l}\text { A S R COLLEGE OF ENGINEERING AND } \\
\text { TECHNOLOGY }\end{array}$ & JNTU KAKINADA & 2010 & ASRK \\
\hline ADITYA ENGINEERING COLLEGE & JNTU KAKINADA & 2001 & ADTP \\
\hline $\begin{array}{l}\text { BADARI INSTITUTE OF TECHNOLOGY AND } \\
\text { SCIENCES FOR WOMEN }\end{array}$ & JNTU KAKINADA & 2009 & BITW \\
\hline $\begin{array}{l}\text { CHAITANYA INSTITUTE OF SCIENCES AND } \\
\text { TECHNOLOGY }\end{array}$ & JNTU KAKINADA & 2005 & CHKN \\
\hline IDEAL INSTITUTE OF TECHNOLOGY & JNTU KAKINADA & 2009 & IDEL \\
\hline $\begin{array}{l}\text { KAKINADA INSTITUTE OF ENGINEERING } \\
\text { AND TECHNOLOGY }\end{array}$ & JNTU KAKINADA & 2001 & KIET \\
\hline $\begin{array}{l}\text { KAKINADA INSTITUTE OF ENGINEERING } \\
\text { AND TECHNOLOGY }\end{array}$ & JNTU KAKINADA & 2009 & KIEK \\
\hline $\begin{array}{l}\text { KAKINADA INSTITUTE OF ENGINEERING } \\
\text { AND TECHNOLOGY FOR WOMEN }\end{array}$ & JNTU KAKINADA & 2008 & KIEW \\
\hline SRI ADITYA ENGINEERING COLLEGE & JNTU KAKINADA & 2008 & SACS \\
\hline $\begin{array}{l}\text { SRI SAI ADITYA INSTITUTE OF SCIENCES } \\
\text { AND TECHNOLOGY }\end{array}$ & JNTU KAKINADA & 2004 & SISS \\
\hline
\end{tabular}

\begin{tabular}{|c|c|c|c|c|c|c|}
\hline \multirow[t]{2}{*}{ College } & \multicolumn{2}{|c|}{$\begin{array}{l}\text { Questionnaire } \\
\text { Distributed }\end{array}$} & \multicolumn{2}{|c|}{$\begin{array}{l}\text { Questionnaire } \\
\text { Received }\end{array}$} & \multirow[t]{2}{*}{$\begin{array}{c}\text { Total } \\
\text { Respondents }\end{array}$} & \multirow[t]{2}{*}{$\begin{array}{l}\text { Respondent } \\
\text { Percentage }\end{array}$} \\
\hline & Male & Female & Male & Female & & \\
\hline ASRK & 24 & 16 & 21 & 14 & 35 & 87.50 \\
\hline ADTP & 24 & 16 & 20 & 15 & 35 & 87.50 \\
\hline BITW & 24 & 16 & 19 & 11 & 30 & 75.00 \\
\hline CHKN & 24 & 16 & 18 & 12 & 30 & 75.00 \\
\hline IDEL & 24 & 16 & 22 & 14 & 36 & 90.00 \\
\hline KIET & 24 & 16 & 19 & 13 & 32 & 80.00 \\
\hline KIEK & 24 & 16 & 20 & 15 & 35 & 87.50 \\
\hline KIEW & 24 & 16 & 18 & 16 & 34 & 85.00 \\
\hline SACS & 24 & 16 & 19 & 15 & 34 & 85.00 \\
\hline SISS & 24 & 16 & 19 & 16 & 35 & 87.50 \\
\hline TOTAL & & & & & 336 & 84.00 \\
\hline
\end{tabular}

Gender-wise allotment of faculty members according to the number of questionnaire distributed and the rejoinder received is tabulated in Table 2. The examined data in Table 2 pointed out that a total of 400 questionnaires were disseminated among 240 male and 160 female faculty members. Out of which 336 faculties have responded for filling the questionnaires. So, the overall response rate is $84.00 \%$. Out of 336 faculty members, 195 (58.03\%) of the faculties are male and $141(41.96 \%)$ female. 


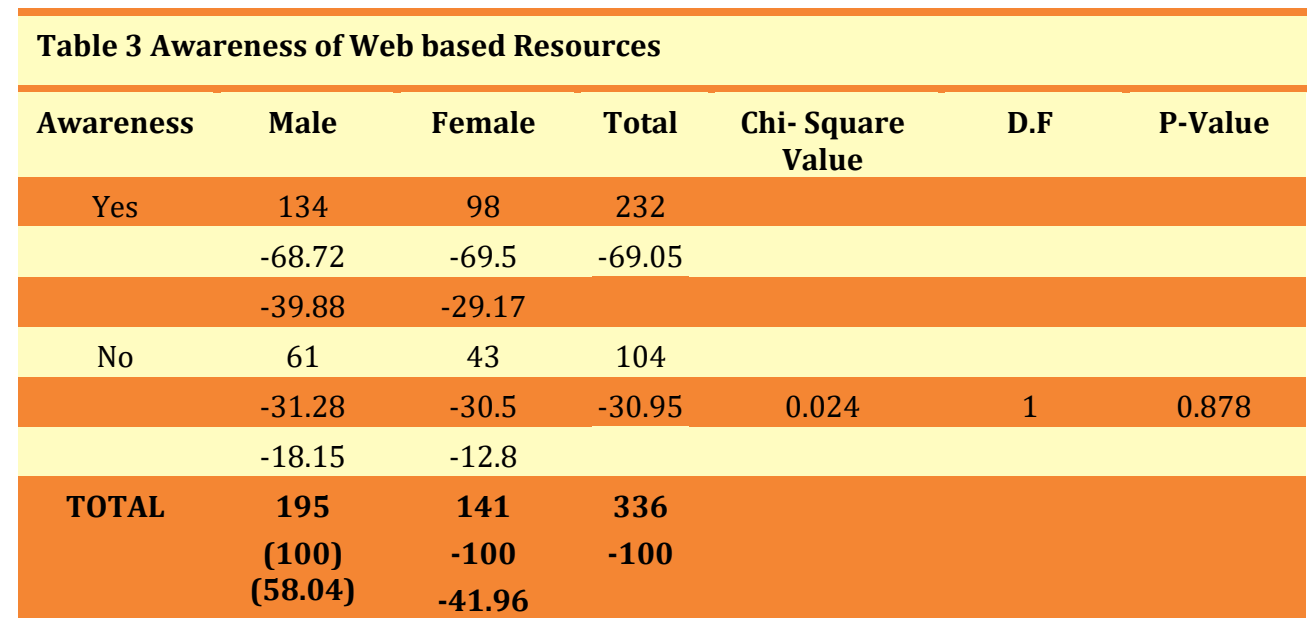

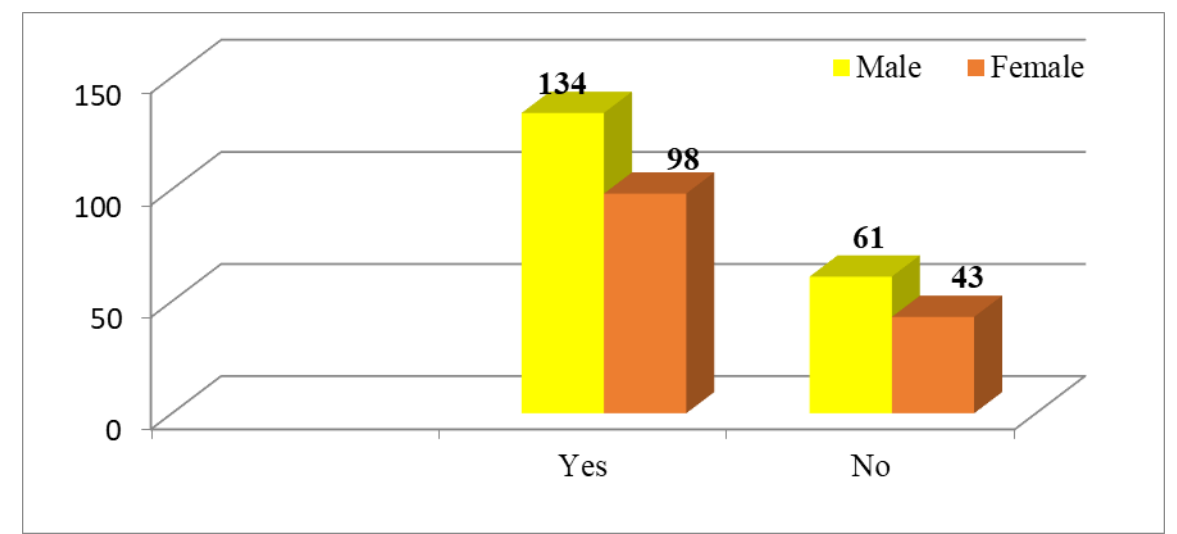

Figure 1 Awareness of Web based Resources

The allocation of faculty according to the attentiveness of Web based resources is given in Table 3. It is apparent from Table that greater part (69.05\%) of the faculty members of engineering was aware about the digital resources, whereas only $30.95 \%$ were not aware of resources. There is no significant relation between awareness of digital resources and gender which is greater $p$ value.

\begin{tabular}{|c|c|c|c|c|c|c|}
\hline Purpose & Male & Female & Total & $\begin{array}{l}\text { Chi- } \\
\text { Square } \\
\text { Value }\end{array}$ & D.F & $\begin{array}{c}\text { P- } \\
\text { Value }\end{array}$ \\
\hline \multirow[t]{3}{*}{ For Communication } & 39 & 34 & 73 & & & \\
\hline & $(20.00)$ & $(24.10)$ & (21.73) & & & \\
\hline & (11.61) & $(22.70)$ & & & & \\
\hline \multirow[t]{3}{*}{ To modernize knowledge } & 58 & 36 & 94 & & & \\
\hline & $(29.74)$ & $(25.53)$ & $(27.98)$ & & & \\
\hline & $(17.26)$ & $(25.53)$ & & & & \\
\hline \multirow[t]{3}{*}{ Teaching and research Work } & 62 & 39 & 101 & 2.346 & 3 & 0.504 \\
\hline & $(31.79)$ & $(27.66)$ & $(30.06)$ & & & \\
\hline & $(18.45)$ & $(27.66)$ & & & & \\
\hline
\end{tabular}


B. Vinoda and Dr. B. R. Doraswamy Naick

$\begin{array}{cccc}\begin{array}{l}\text { To Collect Subject information } \\ \text { for Career Development }\end{array} & 36 & 32 & 68 \\ & (18.46) & (22.70) & (20.24) \\ \text { TOTAL } & (10.71) & (22.70) & \\ & \mathbf{1 9 5} & \mathbf{1 4 1} & 336 \\ & (\mathbf{1 0 0 )} & \mathbf{( 1 0 0 )} & \mathbf{1 0 0 )} \\ & \mathbf{( 5 8 . 0 3 6 )} & (\mathbf{4 1 . 9 6 )} & \end{array}$

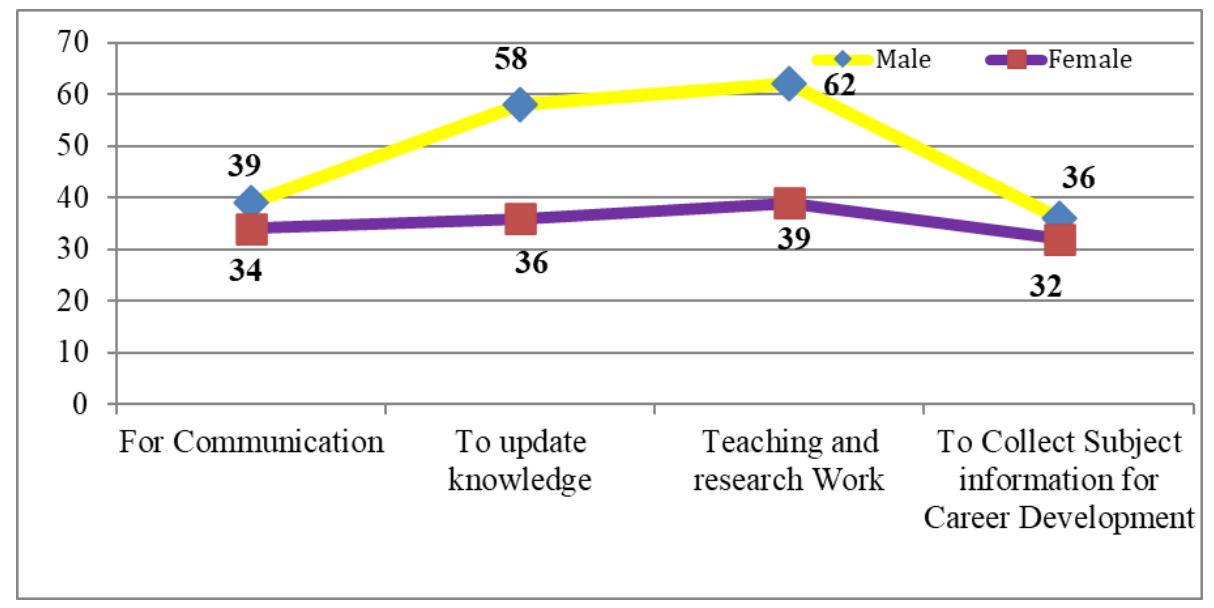

Figure 2 Purpose of Using Web based Resources

The data in Table 4 and Figure 2 depicts that 101(30.06\%) of the faulty were using Web based resources for teaching and research work, 94(27.98\%) for update knowledge purpose, $73(21.73 \%)$ for communication, and 68(20.24\%) for collect subject information for career development purpose using digital resources for their career development. There is no significant relation between purpose of using digital resources and gender which is greater $\mathrm{p}$ value.

\begin{tabular}{|c|c|c|c|c|c|c|}
\hline \multicolumn{7}{|c|}{ Table 5 Access and Use of Web based Resources } \\
\hline Digital Resources & Male & Female & Total & $\begin{array}{c}\text { Chi- Square } \\
\text { Value }\end{array}$ & D.F & $\begin{array}{c}\text { P- } \\
\text { Value }\end{array}$ \\
\hline \multirow[t]{3}{*}{ E- Journals } & 53 & 44 & 97 & & & \\
\hline & $(27.18)$ & $(31.21)$ & $(28.87)$ & & & \\
\hline & $(15.77)$ & $(13.10)$ & & & & \\
\hline \multirow[t]{3}{*}{ E- Books } & 22 & 14 & 36 & & & \\
\hline & $(11.28)$ & $(9.93)$ & $(10.71)$ & & & \\
\hline & $(6.55)$ & $(4.17)$ & & & & \\
\hline \multirow[t]{3}{*}{ E- News Papers } & 17 & 15 & 32 & & & \\
\hline & $(8.72)$ & $(10.64)$ & $(9.52)$ & & & \\
\hline & $(5.06)$ & $(4.46)$ & & & & \\
\hline \multirow[t]{3}{*}{ E-Zines } & 16 & 3 & 19 & & & \\
\hline & & & & & & \\
\hline & $(4.76)$ & $(0.89)$ & & & & \\
\hline \multirow[t]{3}{*}{ Online databases } & 24 & 35 & 59 & 18.256 & 7 & 0.011 \\
\hline & (12.31) & (24.82) & & & & \\
\hline & (24.82) & (10.42) & & & & \\
\hline
\end{tabular}




\begin{tabular}{|c|c|c|c|}
\hline $\begin{array}{l}\text { E-Thesis and } \\
\text { Projects }\end{array}$ & $\begin{array}{c}12 \\
(6.15) \\
(3.57)\end{array}$ & $\begin{array}{c}8 \\
(5.67) \\
(2.38)\end{array}$ & $\begin{array}{c}20 \\
(5.95)\end{array}$ \\
\hline Internet \OPAC & $\begin{array}{c}39 \\
(20.00) \\
(11.61)\end{array}$ & $\begin{array}{c}15 \\
(10.64) \\
(11.61)\end{array}$ & $\begin{array}{c}54 \\
(16.07)\end{array}$ \\
\hline CD-ROM & $\begin{array}{c}12 \\
(6.15) \\
(2.08)\end{array}$ & $\begin{array}{c}7 \\
(4.96) \\
(2.08)\end{array}$ & $\begin{array}{c}19 \\
(5.65)\end{array}$ \\
\hline TOTAL & $\begin{array}{c}195 \\
(100) \\
(58.036)\end{array}$ & $\begin{array}{c}141 \\
(100) \\
(41.96)\end{array}$ & $\begin{array}{c}195 \\
(100) \\
(58.036)\end{array}$ \\
\hline
\end{tabular}

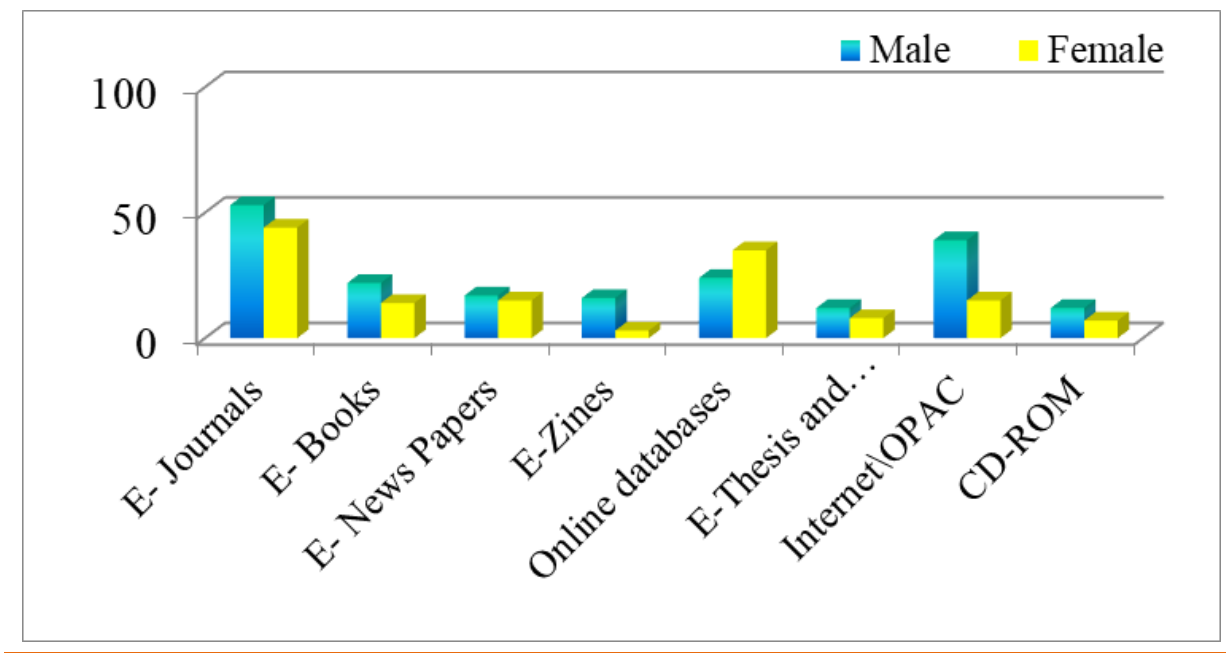

Figure 3 Access and Use of Digital Resources

The data in Table 5 demonstrate the use of Web based resources by the faculty. It is exposed that $28.87 \%$ of the respondents who use E-journals, next by online databases are used by $17.56 \%$ respondents, followed by Internet which is used by $16.07 \%$ respondents. A percentage of 54 respondents use library OPAC (Online Public Access Catalogue), follows by e-books are used $10.71 \%$ of users, followed by E-newspapers which is used by $9.52 \%$ respondents, $5.95 \%$ of respondents using ethesis and projects, $5.65 \%$ of respondents using CD-ROM databases, and E- zines. There is a significant relation between access and use of digital resources and gender which is lesser $\mathrm{p}$ value.

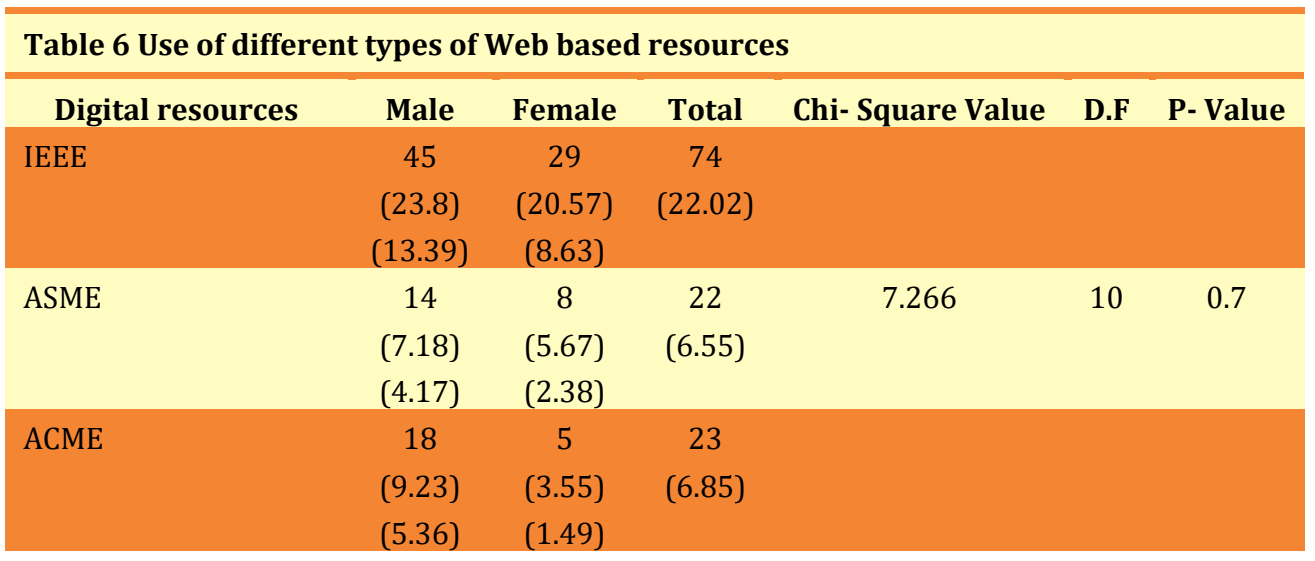


B. Vinoda and Dr. B. R. Doraswamy Naick

\begin{tabular}{|c|c|c|c|}
\hline Springer link & $\begin{array}{c}2 \\
(1.03) \\
(0.60)\end{array}$ & $\begin{array}{c}1 \\
(0.71) \\
(0.30)\end{array}$ & $\begin{array}{c}3 \\
(0.89)\end{array}$ \\
\hline INDEST-AICTE & $\begin{array}{c}2 \\
(1.03) \\
(0.60)\end{array}$ & $\begin{array}{c}2 \\
(1.42) \\
(0.60)\end{array}$ & $\begin{array}{c}4 \\
(1.19)\end{array}$ \\
\hline DELNET & $\begin{array}{c}39 \\
(20.0) \\
(11.61)\end{array}$ & $\begin{array}{c}35 \\
(24.82) \\
(10.42)\end{array}$ & $\begin{array}{c}74 \\
(22.02)\end{array}$ \\
\hline J-GATE & $\begin{array}{c}43 \\
(22.05) \\
(12.80)\end{array}$ & $\begin{array}{c}34 \\
(24.11) \\
(10.12)\end{array}$ & $\begin{array}{c}77 \\
(22.92)\end{array}$ \\
\hline NPTEL & $\begin{array}{c}18 \\
(9.23) \\
(5.36)\end{array}$ & $\begin{array}{c}19 \\
(13.48) \\
(5.65)\end{array}$ & $\begin{array}{c}37 \\
(11.01)\end{array}$ \\
\hline Proquest & $\begin{array}{c}4 \\
(2.05) \\
(1.19)\end{array}$ & $\begin{array}{c}2 \\
(1.42) \\
(0.60)\end{array}$ & $\begin{array}{c}6 \\
(1.79)\end{array}$ \\
\hline EBSCO & $\begin{array}{c}3 \\
(1.54) \\
(0.89)\end{array}$ & $\begin{array}{c}2 \\
(1.42) \\
(0.60)\end{array}$ & $\begin{array}{c}5 \\
(1.49)\end{array}$ \\
\hline Open access Databases & $\begin{array}{c}7 \\
(3.59) \\
(2.08)\end{array}$ & $\begin{array}{c}4 \\
(2.84) \\
(1.19)\end{array}$ & $\begin{array}{c}11 \\
(3.27)\end{array}$ \\
\hline TOTAL & $\begin{array}{c}195 \\
(100) \\
(58.04)\end{array}$ & $\begin{array}{c}141 \\
(100) \\
(41.96)\end{array}$ & $\begin{array}{c}336 \\
(100)\end{array}$ \\
\hline
\end{tabular}

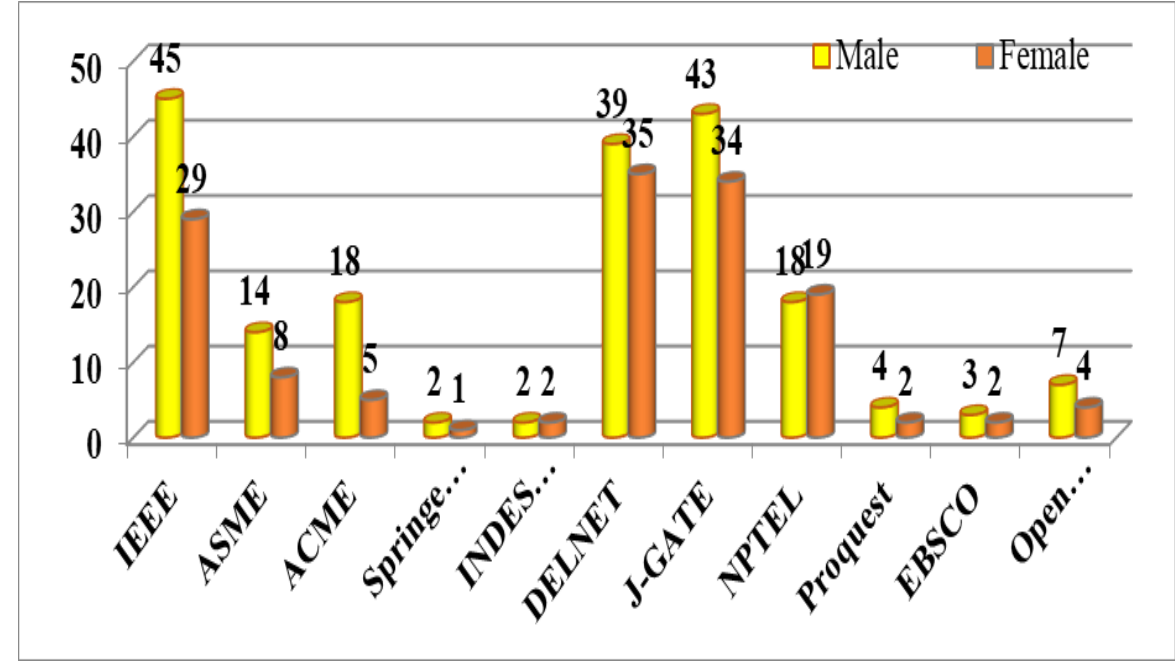

Figure 4 Use of different types of digital resources

Table 6 and Figure 4 illustrate that 22.692\% were aware about the J-Gate resources, followed by $22.02 \%$ aware about the IEEE journals and DELNET resources. A percentage of $11.01 \%$ respondents are aware about the NPTEL resources, followed by ASME/ASCE resources 7.85\%/ 6.55\% and Open access 
databases $3.27 \%$. Only few of the faculty members are aware about the Proquest $1.79 \%$ and EBSCO $1.49 \%$ and $1.19 \%$ aware about AICTE-INDEST and least aware about $0.89 \%$ of Springer digital resources. There is no significant relation between use of digital resources and gender which is greater $p$ value.

\begin{tabular}{|c|c|c|c|c|c|c|}
\hline Digital Resources & Male & Female & Total & Chi-Square Value & D.F & P-Value \\
\hline \multirow[t]{3}{*}{ E- Journals } & 59 & 44 & 103 & & & \\
\hline & $(30.26)$ & $(31.21)$ & $(30.65)$ & & & \\
\hline & $(17.56)$ & $(13.10)$ & & & & \\
\hline \multirow[t]{3}{*}{ E- Books } & 21 & 15 & 36 & & & \\
\hline & (10.77) & $(10.64)$ & (10.71) & & & \\
\hline & $(6.25)$ & $(4.46)$ & & & & \\
\hline \multirow[t]{3}{*}{ E- News Papers } & 18 & 12 & 30 & & & \\
\hline & (9.23) & $(8.51)$ & (8.93) & & & \\
\hline & $(5.36)$ & (3.57) & & & & \\
\hline \multirow[t]{3}{*}{ E-Zines } & 11 & 3 & 14 & & & \\
\hline & $(5.64)$ & $(2.13)$ & $(4.17)$ & & & \\
\hline & (3.27) & $(0.89)$ & & & & \\
\hline \multirow[t]{3}{*}{ Online databases } & 26 & 35 & 61 & 11.598 & 7 & 0.115 \\
\hline & (13.33) & $(24.82)$ & (18.15) & & & \\
\hline & $(7.74)$ & $(10.42)$ & & & & \\
\hline \multirow[t]{3}{*}{ E-Thesis and Projects } & 12 & 8 & 20 & & & \\
\hline & $(6.15)$ & (5.67) & $(5.95)$ & & & \\
\hline & (3.57) & $(2.38)$ & & & & \\
\hline \multirow[t]{3}{*}{ Internet \OPAC } & 39 & 17 & 56 & & & \\
\hline & $(20.00)$ & $(12.06)$ & (16.67) & & & \\
\hline & (11.61) & $(5.06)$ & & & & \\
\hline \multirow[t]{3}{*}{ CD-ROM } & 9 & 7 & 16 & & & \\
\hline & $(4.62)$ & $(4.96)$ & $(4.76)$ & & & \\
\hline & $(2.68)$ & $(2.08)$ & & & & \\
\hline \multirow[t]{3}{*}{ TOTAL } & 195 & 141 & 336 & & & \\
\hline & (100) & (100) & $(100)$ & & & \\
\hline & (58.04) & $(41.96)$ & & & & \\
\hline
\end{tabular}

The data in above Table shows the faculty opinioned of availability of Web based resources. Out of 336 responses, $13(30.65 \%) \%$ of the faculty indicate that the library have facility of good E-journal access, followed by $61(18.15 \%)$ who have opined that the library has good online databases, $56(16.67 \%)$ faculty opinioned that Internet/OPAC facility is good, $36(10.71 \%)$ are of the opinion that the library has a good number of E-Books, 30(8.93\%) of the faculty members have opined that good collection of E- News apers is available in their library, 20(5.95\%) of the users opinioned that the library have good collection of E-thesis and Projects $16(4.76 \%)$ of the faculty members have opined that there are good CD-ROM Databases facility in their library, only $14(4.17 \%)$ of users opinioned that the collection of E-Zines were less collection.

There is a significant relation between Opinion about the availability and gender which is lesser $\mathrm{p}$ value. 


\begin{tabular}{|c|c|c|c|c|c|c|}
\hline Digital Resources & Male & Female & Total & Chi- Square Value & D.F & P-Value \\
\hline Time Consuming & $\begin{array}{c}30 \\
(15.38) \\
(8.93)\end{array}$ & $\begin{array}{c}18 \\
(12.77) \\
(5.36)\end{array}$ & $\begin{array}{c}48 \\
(14.29)\end{array}$ & & & \\
\hline Costly & $\begin{array}{c}20 \\
(10.26) \\
(5.95)\end{array}$ & $\begin{array}{c}15 \\
(10.64) \\
(4.46)\end{array}$ & $\begin{array}{c}35 \\
(10.42)\end{array}$ & & & \\
\hline Easy to use & $\begin{array}{c}40 \\
(20.51) \\
(11.90)\end{array}$ & $\begin{array}{c}30 \\
(21.28) \\
(8.93)\end{array}$ & $\begin{array}{c}70 \\
(20.83)\end{array}$ & & & \\
\hline More Useful & $\begin{array}{c}25 \\
(12.82) \\
(7.44)\end{array}$ & $\begin{array}{c}17 \\
(12.06) \\
(5.06)\end{array}$ & $\begin{array}{c}42 \\
(12.50)\end{array}$ & 0.831 & 6 & 0.991 \\
\hline More Preferred & $\begin{array}{c}28 \\
(14.36) \\
(8.33)\end{array}$ & $\begin{array}{c}19 \\
(13.48) \\
(5.65)\end{array}$ & $\begin{array}{c}47 \\
(13.99)\end{array}$ & & & \\
\hline More Interactive & $\begin{array}{c}27 \\
(13.85) \\
(8.04)\end{array}$ & $\begin{array}{c}21 \\
(8.04) \\
(6.25)\end{array}$ & $\begin{array}{c}48 \\
(14.29)\end{array}$ & & & \\
\hline More informative & $\begin{array}{c}25 \\
(12.82) \\
(7.44)\end{array}$ & $\begin{array}{c}21 \\
(14.89) \\
(6.25)\end{array}$ & $\begin{array}{c}46 \\
(13.69)\end{array}$ & & & \\
\hline TOTAL & $\begin{array}{c}195 \\
(100) \\
(58.04)\end{array}$ & $\begin{array}{c}141 \\
(100) \\
(41.96)\end{array}$ & $\begin{array}{c}336 \\
(100)\end{array}$ & & & \\
\hline
\end{tabular}

Above Table shows the comparison of Web based resources with the print resources. It clearly shows that $70(20.83 \%)$ respondents have the view that print resources are Easy to Use. A percentage of 48(14.29\%) respondents have the view that print resources are more interactive and time consuming when compared with the digital resources, $47(13.99 \%)$ of the respondents have digital resources are more preferred than the print resources,46(13.69\%) have the view that digital resources are more informative $42(12.5 \%)$ of the responds have digital resources are more useful than print resources, $35(10.42 \%)$ of users compare the digital resources are costly that the print resources.

There is no significant relation between Comparison between Web based resources with resources and gender which is greater $\mathrm{p}$ value.

Table 9 Features of Web based resources over print resources

\begin{tabular}{|ccccccc}
\hline Digital Resources & Male & Female & Total & Chi- Square Value & D.F & P-Value \\
Easy Downloaded & 24 & 13 & 37 & 3.005 & 6 & 0.808 \\
& $(12.31$ & $(9.22)$ & $(11.01)$ & & & \\
Access from any location & $(7.14)$ & $(3.87)$ & & & \\
& $(17.95)$ & 22 & 57 \\
& $(10.42)$ & $(6.55)$ & & & & \\
& & & & & \\
& &
\end{tabular}




\begin{tabular}{|lccc}
\hline Easy to search & 46 & 41 & 87 \\
& $(23.59)$ & $(29.08)$ & $(25.89)$ \\
& $(13.69)$ & $(12.20)$ & \\
Easy Format & 23 & 21 & 44 \\
& $(11.79)$ & $(14.89)$ & $(13.10)$ \\
& $(6.85)$ & $(6.25)$ & \\
Hyperlinks to references & 24 & 17 & 41 \\
& $(12.31)$ & $(12.06)$ & $(12.20)$ \\
Speed of Publication & $(7.14)$ & $(5.06)$ & \\
& 14 & 10 & 24 \\
& $(7.18)$ & $(7.09)$ & $(7.14)$ \\
& $(4.17)$ & $(2.98)$ & \\
E-mail alerts & 29 & 17 & 46 \\
& $(14.87)$ & $(12.06)$ & $(13.69)$ \\
& $(8.63)$ & $(5.06)$ & \\
TOTAL & $\mathbf{1 9 5}$ & $\mathbf{1 4 1}$ & $\mathbf{3 3 6}$ \\
& $\mathbf{( 1 0 0 )}$ & $\mathbf{( 1 0 0 )}$ & $\mathbf{( 1 0 0 )}$ \\
& $\mathbf{( 5 8 . 0 4 )}$ & $\mathbf{( 4 1 . 9 6 )}$ &
\end{tabular}

Table 9 shows the features of Web based resources over print resources. Most of the faculty members that is $87(25.89 \%)$ have opined that Easy to search are the best feature in comparison to print resources, followed by $57(16.96 \%)$ are Access from any location, 46(13.69\%) have opined about e-mail alerts, 44(13.10\%) have opined that Easy formats, 41(12.20\%) about hyperlinks to references and $37(11.01 \%)$ of the respondents have opined that digital resources can easy downloaded from any location compare with print resources and only 24(7.14\%) are opined that digital resources are speed publication that print resources.

There is no significant relation between Features of Web based resources over print resources and gender which is greater $p$ value.

Table 10 Problems faced while using Web based library resources

\begin{tabular}{|c|c|c|c|c|c|c|}
\hline Digital Resources & Male & Female & Total & $\begin{array}{l}\text { Chi- Square } \\
\text { Value }\end{array}$ & D.F & $\begin{array}{c}\text { P- } \\
\text { Value }\end{array}$ \\
\hline Limited computers & $\begin{array}{c}36 \\
(18.46) \\
(10.71)\end{array}$ & $\begin{array}{c}23 \\
(16.31) \\
(6.85)\end{array}$ & $\begin{array}{c}59 \\
(17.56)\end{array}$ & & & \\
\hline $\begin{array}{l}\text { Be short of sufficient } \\
\text { information }\end{array}$ & $\begin{array}{c}26 \\
(13.33) \\
(7.74)\end{array}$ & $\begin{array}{c}18 \\
(12.77) \\
(5.36)\end{array}$ & $\begin{array}{c}44 \\
(13.10)\end{array}$ & & & \\
\hline Internet speed is slow & $\begin{array}{c}56 \\
(28.72) \\
(16.67)\end{array}$ & $\begin{array}{c}42 \\
(29.79) \\
(12.50)\end{array}$ & $\begin{array}{c}98 \\
(29.17)\end{array}$ & & & \\
\hline $\begin{array}{l}\text { Be short of sufficient E- } \\
\text { resources }\end{array}$ & $\begin{array}{c}48 \\
(24.62) \\
(14.29)\end{array}$ & $\begin{array}{c}37 \\
(26.24) \\
(11.01)\end{array}$ & $\begin{array}{c}85 \\
(25.30)\end{array}$ & 0.364 & 5 & 0.996 \\
\hline $\begin{array}{l}\text { Be short of assistance by } \\
\text { library staff }\end{array}$ & $\begin{array}{c}12 \\
(6.15) \\
(3.57)\end{array}$ & $\begin{array}{c}9 \\
(6.38) \\
(2.68)\end{array}$ & $\begin{array}{c}21 \\
(6.25)\end{array}$ & & & \\
\hline Be short of time & 17 & 12 & 29 & & & \\
\hline
\end{tabular}




$\begin{array}{cccc} & (8.72) & (8.51) & (8.63) \\ & (5.06 & (3.57) & \\ \text { TOTAL } & \mathbf{1 9 5} & \mathbf{1 4 1} & \mathbf{3 3 6} \\ & (\mathbf{1 0 0 )} & \mathbf{( 1 0 0 )} & (\mathbf{1 0 0 )} \\ & (\mathbf{5 8 . 0 4 )} & (\mathbf{4 1 . 9 6 )} & \end{array}$

Table 10 raveled that the troubles faced though utilizing the Web based resources by the faculty of. Preponderance of the respondents that is $98(29.17 \%)$ have faced difficulty due to slow internet speed. It was followed by $85(25.30 \%)$ respondents who faced short of sufficient e- resources, lack of sufficient Eresources, $59(17.56 \%)$ respondents limited computers, $44(13.10 \%)$ be short of sufficient information, 29(8.63\%) respondents express lack of time, and 21(6.25\%) responded express short of assistance by library staff.

There is no significant relation between Problems faced while using Web based library resources and gender which is greater $\mathrm{p}$ value.

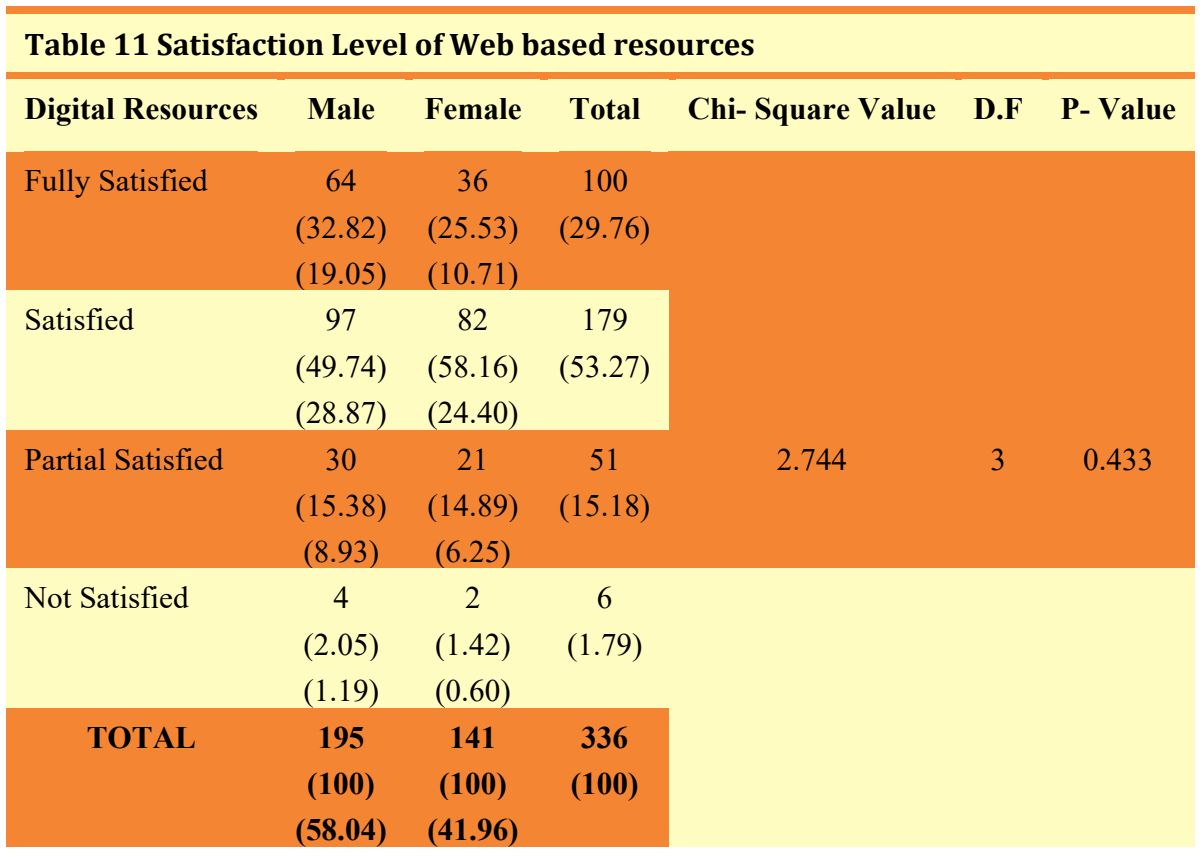

Table 11 designated that the greater part of the faculty members that is $179(53.27 \%)$ are satisfied with the accessibility of Web based resources in their libraries. It is followed by $100(29.76 \%)$ of the faculty members who are fully satisfied, 51(15.18\%) partially satisfied with the accessibility of digital resources and $6(1.79 \%)$ of the faculty members who are not at all satisfied with the Web based resources accessible in their library.

There is no significant relation between Satisfaction Level and gender which is greater $\mathrm{p}$ value.

\section{FINDINGS}

- In the present study, majority of the faculty of engineering were aware about the Web based resources.

- $27.98 \%$ of the faculty were using Web based resources for bring up to date Knowledge, 
- Majority $30.06 \%$ of the faulty were utilizing Web based resources for teaching and research work purpose.

- Majority of the faculty members are aware about the E-Journals

- More faculty members have opined that Web based resources are easy to search when comparison to the print resources.

- Majority of the faculty members have expressed slow internet is the common problems for accessing Web based resources.

- It is also found from the study that majority of the faculty members are satisfied with available Web based resources.

\section{CONCLUSION}

Web based resources are producing a revolution in engineering college libraries. These have rapidly changed the way of on the lookout for and disseminate information, greater part of the engineering college faculty members are aware of the availability of Web based resources in their respective libraries and therefore are accessing them. Some of the faculty members are unaware and have not used online thesis/ dissertations, abstracts/indexes and online databases, which are very relevant for their study and research. So, the libraries can take initiatives to organise awareness programmes in digital area. This study helps the librarians to know the consequence of Web based resources in academic and research environment particularly in engineering colleges. However, all libraries have reasonable Web based resource facilities at their end. Engineering libraries should rationalize their information-resource management activities in line with global level.

\section{REFERENCES}

Bhat, shivananda Dr; TP, Prasad; and Rao, Mahabaleshwara Dr (2021). "Awareness and Utilization of Information Resources and Services among Library Users of JCBM College, Shringeri, India: A Study" (2021). Library Philosophy and Practice (e-journal). 6477. Retrieved from https://digitalcommons.unl.edu/libphilprac/6477.

Deenadhayalu, B,(2021). Digital Information Seeking Behaviour of Engineering Faculty Members in Rayalaseema Region of A.P., India-A Study (2021). Library Philosophy and Practice (e-journal). 5925. Retrieved from https://digitalcommons.unl.edu/libphilprac/5925.

Mohan, Meenu and Devi B, Mini (2021). "Use of Print and Electronic Resources among the Post-Graduate Students in the Teaching Departments of University of Kerala, Thiruvananthapuram" (2021). Library Philosophy and Practice (e-journal). $4998 . \quad$ Retrieved from https://digitalcommons.unl.edu/libphilprac/4998

Naik, Lokesha Dr. and S, Kishore Kumar Dr (2021). "Users Attitudes towards Library Resource and Services of First Grade College in Bangalore City, India: A Study" (2021). Library Philosophy and Practice (e-journal). 6390. Retrieved from https://digitalcommons.unl.edu/libphilprac/6390

Raja Suresh Kumar Pitla, Rama Krishna Kona, and Gowridevi, R. (2020). Use of electronic information resources in engineering college libraries. Library Philosophy and Practice (e-journal). Retrieved from https://digitalcommons.unl.edu/libphilprac/4088

Ravi Kumar Annabathuni, Raja Suresh Kumar Pitla; and Doraswamy Naick B. R. (2021). Accessibility of Library Resources at KIET Group of Institutions, Kakinada, Andhra Pradesh, India. Library Philosophy and Practice (e- 
B. Vinoda and Dr. B. R. Doraswamy Naick

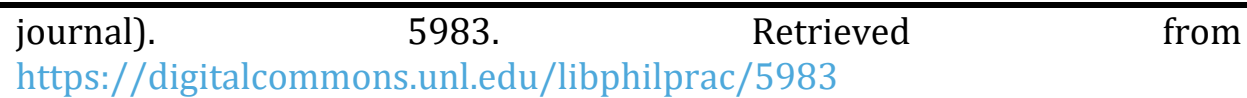

Singh H and Mahajan P, (2021). Use of e-resources in the University Libraries of Northern India: A Comparative Study. PEARL - A Journal of Library and Information Science, Vol. 15, No. 2, pp. 86-96.

Vinoda B., Raja Suresh Kumar Pitla,; and Doraswamy Naick, B. R., (2021). "Utilization of Library Information Sources And Services In The Engineering Colleges: A Case Study" (2021). Library Philosophy and Practice (e-journal). 5778. Retrieved from https://digitalcommons.unl.edu/libphilprac/5778 